\title{
Cervical necrotising fasciitis presenting with mild symptoms
}

\author{
Pavlos Pantos, Georgios Chrysovitsiotis (1) , Efthymios Kyrodimos, \\ Aristeidis Chrysovergis
}

1st Otorhinolaryngology Dpt, National and Kapodistrian University of Athens School of Medicine, Athens, Attiki, Greece

\section{Correspondence to} Georgios Chrysovitsiotis; chrysovi@gmail.com

Accepted 23 February 2021
Check for updates

(c) BMJ Publishing Group Limited 2021. No commercial re-use. See rights and permissions. Published by BMJ.

\begin{tabular}{|l|}
\hline To cite: Pantos $P_{1}$ \\
Chrysovitsiotis $G_{\text {, }}$ \\
Kyrodimos E, et al. BMJ Case \\
Rep 2021;14:e241925. \\
doi:10.1136/bcr-2021- \\
241925 \\
\hline
\end{tabular}

\section{DESCRIPTION}

A 75 -year-old male patient presented to the emergency department complaining of a mildly painful swelling on the left side of his neck that developed over the past 3 days. He reported a maximum temperature of $37.5^{\circ} \mathrm{C}$ and no other symptom. The patient is a smoker and is under medication for hypertension and dyslipidaemia.

Clinical examination revealed a swelling occupying the left anterior cervical triangle, warm and mildly tender to palpation, with erythema of the overlying skin. The left submandibular gland was palpated enlarged, although soft and painless. Rhinopharyngolaryngoscopy with flexible fiberscope showed mild protrusion of the posterior and the left lateral pharyngeal walls. The patient's white cell count was $17.620 \times 10^{9} / \mathrm{L}$ and $\mathrm{C}$ reactive protein was $308 \mathrm{mg} / \mathrm{L}$. A CT with intravenous contrast was performed, demonstrating submucosal gas accumulation and multiple microabscesses in the retropharyngeal space, along with soft tissue swelling of the left neck (figure 1A).

Cervical necrotising fasciitis (CNF) was highly suspected and despite the patient's mild symptoms, immediate surgical treatment was decided. Intraoperatively, necrotic tissue was recognised and removed. The retropharyngeal and left parapharyngeal, submandibular and submental spaces were explored and debrided (figure 1B,C). We subsequently contemplated closure by tertiary intention. Tissue necrosis was not extensive, bleeding edges have been encountered in every aspect of the wound, following excision of the last necrotic sites and the patient had been stable with mild symptoms. After taking all these facts into account, we decided to apply a few skin sutures, without subcutaneous layer. Penrose tubes were also placed. Postoperatively, the patient reported no pain and all his vital signs were normal. Tissue and pus cultures showed growth of Fusobacterium varium, with sensitivity to the antibiotic regimen already administered, which included meropenem, vancomycin and metronidazole. The surgical wound was attended many times a day, showing improvement (figure 1D).

On the third postoperative day, an erythematous, tender swelling had developed at the level of the left clavicle, extending to the sternal notch (figure 2A,B). Despite this development, the patient still reported no pain, his vital signs were normal, as was the laboratory workout. A second CT demonstrated subcutaneous gas and small abscesses in the supraclavicular area and the anterior thoracic wall (figure 2C). A subcutaneous abscess was surgically drained followed by thorough debridement of the necrotic tissue.

The patient showed progressive improvement and delayed closure of the wounds was performed after 4 weeks of hospitalisation (figure 2D). The patient was discharged 5 days later and showed no signs of recurrence or complications, on regular follow-up.

CNF is a well-known infection that spreads rapidly along the fascial planes, causing necrosis and an inflammatory response that ultimately compromises arterial perfusion. ${ }^{1}$ It can involve underlying muscles, subcutaneous fat and skin. Most authors conclude that CNF appears to have a predilection for immunocompromised patients. ${ }^{2}{ }^{3}$ It is most often associated with intense pain, even disproportionate to the clinical findings. ${ }^{4}$

With early diagnosis and treatment of CNF being of utmost importance, alertness is necessary when dealing with immunocompetent patients with mild
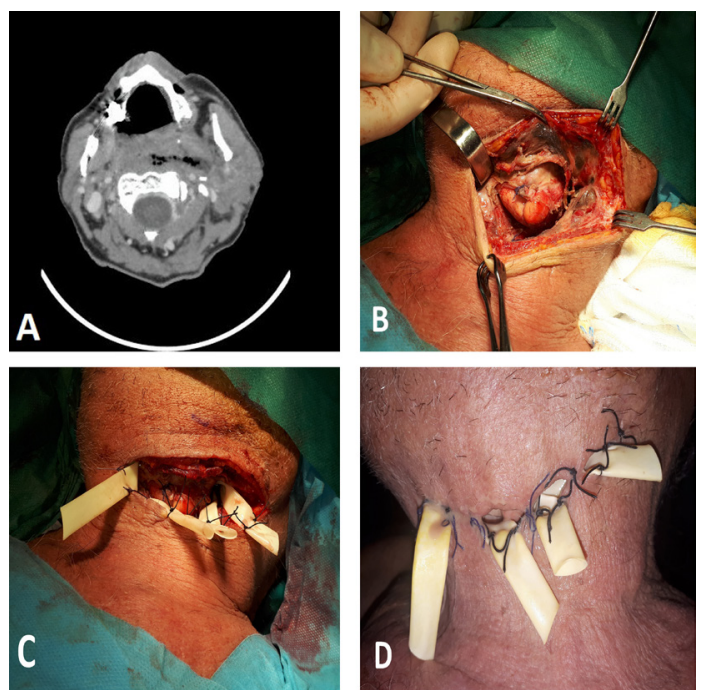

Figure 1 (A) Axial plane image from the CT performed on patient's admission showing gas accumulation in the retropharyngeal space and soft tissue inflammation on the patient's left neck. (B) Intraoperative photograph following drainage of small abscesses and exploration of involved neck spaces. The submandibular gland is notably enlarged. Several necrotic tissue sites are still visible. (C) Intraoperative photograph following completion of surgical debridement. Penrose drainage tubes are placed and the wound is about to be loosely closed. (D) Photograph of the wound on the second postoperative day. Erythema and swelling have subsided. Mild suppurative drainage is still apparent, as expected. 

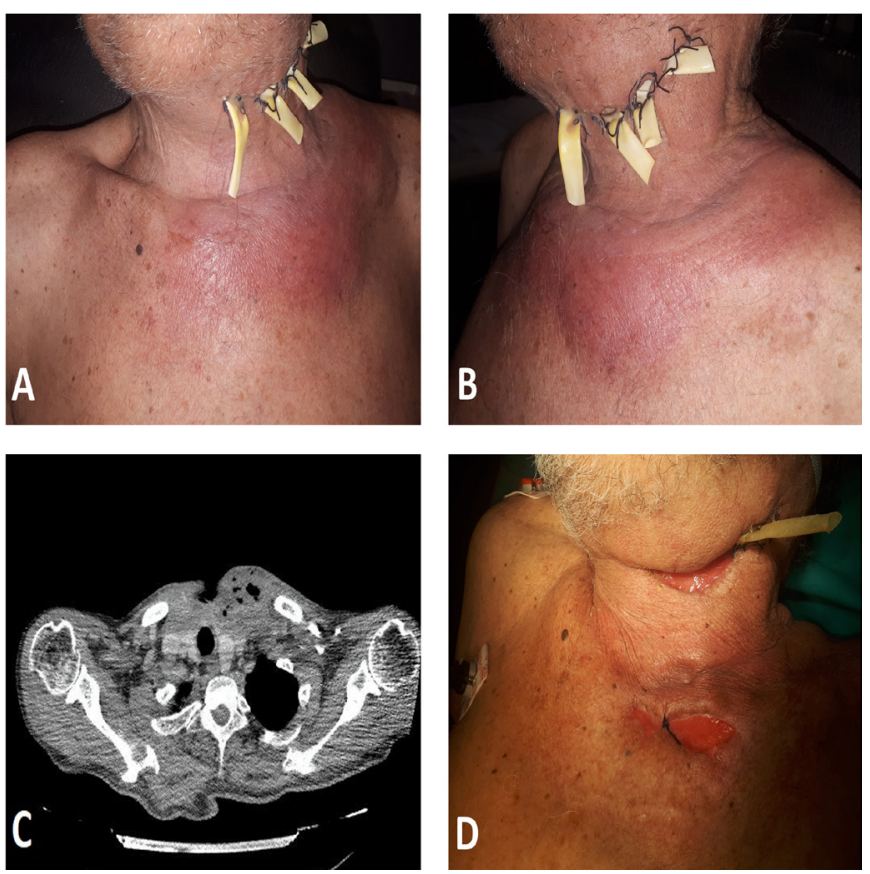

Figure 2 ( $A, B)$ Photograph of the patient on the third postoperative day showing the development of erythema and swelling on the left supraclavicular fossa, extending below the level of the left clavicle and to the sternal notch. (C) Axial plane image from the chest CT performed on the third postoperative day showing subcutaneous gas accumulation and soft tissue inflammation on the left superior thoracic wall. (D) Intraoperative photograph before delayed closure of the surgical wounds. The last penrose tube was removed, the wound lips were debrided and the skin was undermined to achieve less tension. Both wounds were closed with vertical mattress sutures.

symptoms, such as the case we presented. To this end, CT can be invaluable as gas accumulation between tissue is often characteristic of CNF, accelerating proper management. ${ }^{5}$ The rates of multiple surgical interventions or complications are usually high. ${ }^{6}$ This fact was also demonstrated in our patient. The potential effect of the initial loose skin suturing in the development of the infection, despite clinical improvement of the wound, should be considered. A thorough initial surgical debridement cannot replace meticulous postoperative patient monitoring nor allow

\section{Learning points}

- Despite being an aggressive infection, CNF can sometimes present with mild symptoms.

- It has been mostly associated with immunocompromised patients; therefore, high suspicion is necessary to diagnose CNF on patients with immunocompetence.

- Despite early diagnosis and treatment, which are paramount for minimising complications and mortality, prolonged hospitalisation and multiple surgeries cannot be usually avoided.

reluctance to perform prompt further surgical interventions, even on a patient with mild symptoms.

Contributors All authors are clinicians that were involved in the diagnosis and treatment of the case. AC was the primary responsible doctor and along with EK performed the surgical interventions. PP and GC have reviewed the literature and written a first draft that was edited following comments from the rest of the authors. All authors approved the final version of the manuscript and agree to the BMJ Case Reports' submission policies.

Funding The authors have not declared a specific grant for this research from any funding agency in the public, commercial or not-for-profit sectors.

Competing interests None declared.

Patient consent for publication Obtained.

Provenance and peer review Not commissioned; externally peer reviewed.

\section{ORCID iD}

Georgios Chrysovitsiotis http://orcid.org/0000-0001-6734-0542

\section{REFERENCES}

1 Lin C, Yeh F-L, Lin J-T, et al. Necrotizing fasciitis of the head and neck: an analysis of 47 cases. Plast Reconstr Surg 2001;107:1684-93.

2 Gunaratne DA, Tseros EA, Hasan Z, et al. Cervical necrotizing fasciitis: systematic review and analysis of 1235 reported cases from the literature. Head Neck 2018;40:2094-102

3 Oguz H, Yilmaz MS. Diagnosis and management of necrotizing fasciitis of the head and neck. Curr Infect Dis Rep 2012;14:161-5.

4 Wolf $\mathrm{H}$, Rusan M, Lambertsen $\mathrm{K}$, et al. Necrotizing fasciitis of the head and neck. Head Neck 2010;32:1592-6.

5 Becker M, Zbären P, Hermans R, et al. Necrotizing fasciitis of the head and neck: role of CT in diagnosis and management. Radiology 1997;202:471-6.

6 Elander J, Nekludov M, Larsson A, et al. Cervical necrotizing fasciitis: descriptive, retrospective analysis of 59 cases treated at a single center. Eur Arch Otorhinolaryngol 2016;273:4461-7.

Copyright 2021 BMJ Publishing Group. All rights reserved. For permission to reuse any of this content visit

https://www.bmj.com/company/products-services/rights-and-licensing/permissions/

BMJ Case Report Fellows may re-use this article for personal use and teaching without any further permission.

Become a Fellow of BMJ Case Reports today and you can:

- Submit as many cases as you like

- Enjoy fast sympathetic peer review and rapid publication of accepted articles

- Access all the published articles

- Re-use any of the published material for personal use and teaching without further permission

Customer Service

If you have any further queries about your subscription, please contact our customer services team on +44 (0) 2071111105 or via email at support@bmj.com.

Visit casereports.bmj.com for more articles like this and to become a Fellow 